\title{
Perencanaan Pembelajaran Mata Pelajaran Kompetensi Kejuruan Teknik Elektronika Dasar Pada Kompetensi Dasar Menerapkan Macam-Macam Gerbang Dasar Rangkaian Logika Dengan Model Pembelajaran Talking Stick
}

\author{
Dhery Saputra ${ }^{l, *}$, Muhamad Yusro2
}

${ }^{1}$ Mahasiswa Prodi Pendidikan Teknik Elektronika, Fakultas Teknik - UNJ

${ }^{2}$ Dosen Prodi Pendidikan Teknik Elektronika, Fakultas Teknik - UNJ

\begin{abstract}
Abstrak. Perencanaan Pembelajaran Mata Pelajaran Kompetensi Kejuruan Teknik Elektronika Dasar Pada Kompetensi Dasar Menerapkan Macam-macam Gerbang Dasar Rangkaian Logika dengan Model Pembelajaran Talking Stick. Program Studi Pendidikan Teknik Elektronika, Fakultas Teknik Universitas Negeri Jakarta 2016.

Makalah Komprehensif ini ditulis bertujuan untuk membuat Perencanaan Pembelajaran Mata Pelajaran Kompetensi Kejuruan Teknik Elektronika Dasar Pada Kompetensi Dasar Menerapkan Macam-macam Gerbang Dasar Rangkaian Logika Dengan Model Pembelajaran Talking Stick. Perencanaan Pembelajaran ini bertujuan untuk membantu memudahkan proses kegiatan belajar mengajar serta untuk meningkatkan minat dan hasil belajar siswa di SMK. Mata Pelajaran Kompetensi Kejuruan di SMK Jakarta merupakan mata pelajaran Kejuruan yang kompetensinya wajib dikuasai oleh peserta didik.

Perencanaan pembelajaran menggunakan model pembelajaran Talking Stick diharapkan pada peserta didik akan lebih mudah memahami materi pelajaran dan menyelesaikan permasalahan dalam kegiatan pembelajaran, sehingga diharapkan dapat meningkatkan minat dan hasil belajar peserta didik
\end{abstract}

Kata Kunci : Perencanaan Pembelajaran, RPP, Gerbang Logika, Talking Stick

\begin{abstract}
Learning Planning for Vocational Competency Subjects in Basic Electronic Engineering in Basic Competencies of Implementing Various Basic Gates of Logic Circuits with the Talking Stick Learning Model. Electronics Engineering Education Study Program, Faculty of Engineering, State University of Jakarta 2016.

This Comprehensive Paper was written with the aim of making Learning Planning for Vocational Competency Subjects in Basic Electronic Engineering in Basic Competencies of Applying Various Basic Gates of Logic Circuits with the Talking Stick Learning Model. This Learning Planning aims to help facilitate the process of teaching and learning activities and to increase student interest and learning outcomes at SMK. Vocational Competency Subjects at SMK Jakarta are Vocational subjects whose competencies must be mastered by students. Learning planning using the Talking Stick learning model is expected that students will more easily understand the subject matter and solve problems in learning activities, so that it is expected to increase students' interest and learning outcomes.
\end{abstract}

Keywords: Learning Planning, RPP, Logic Gates, Talking Stick

\section{PENDAHULUAN}

Perkembangan ilmu pengetahuan dan teknologi sekarang ini menuntut sumber daya manusia yang berkualitas, sumber daya yang berkualitas adalah manusia yang memahami pengetahuan untuk memecahkan permasalahan yang ada, sehingga berguna bagi kehidupan sendiri dan masyarakat. Pendidikan merupakan kewajiban yang harus kita kenyam semenjak dari lahir, karena dari pendidikan itulah kita akan tahu banyak tentang wawasan di dunia dalam kehidupan ini. Pendidikan berasal dari kata didik, lalu kata ini mendapat awalan sehingga menjadi mendidik artinya memelihara dan memberi latihan. Dalam memelihara dan memberi latihan diperlukan adanya ajaran, tuntutan dan pimpinan mengenai akhlak dan kecerdasan pikiran (KBBI, 1991:232).

Pada umumnya metode pembelajaran yang banyak digunakan guru pada saat ini adalah metode tradisional, yaitu metode penyampaian informasi, ide, atau gagasan dengan tulisan dan lisan. Guru yang berada didepan 
kelas sedangkan siswa hanya mendengar, menyimak, mencatat dan kadangkala diselingi pertanyaan dan latihan sehingga mengakibatkan siswa bertindak pasif. Dalam pelaksanaannya metode ini sering kali membuat suasana belajar jadi monoton karena arah komunikasi satu arah didominasi oleh guru. Kondisi ini dapat menimbulkan kejenuhan dan kebosanan siswa (Trianto. 2007:108-109).

Dari permasalahan di atas, dapat disimpulkan bahwa satu penyebab timbulnya kesulitan siswa untuk memahami pelajaran yang disampaikan oleh gurunya adalah karena kurang tepatnya penggunaan model pembelajaran dalam proses belajar mengajar. Salah satu model pembelajaran yang dimungkinkan mampu menutupi kelemahan model pembelajaran konvensional adalah menggunakan model pembelajaran Talking Stick. Model pembelajaran Talking Stick menekankan kepada proses membaca, memahami dan menjawab pertanyaan, peran siswa dalam model pembelajaran ini adalah membaca, memahami dan menjawab pertanyaan. Sedangkan guru berperan sebagai fasilitator dan pembimbing siswa untuk belajar. Lebih jauh lagi dikatakan bahwa model pembelajaran Talking Stick bertujuan untuk mengembangkan tingkat berfikir intelektualitas, serta keterampilan berfikir kritis (Agus Suprijono. 2010:109).

Diharapkan menggunakan model pembelajaran Talking Stick tersebut, siswa dapat membangun pengetahuan secara aktif dan bersemangat, sehingga siswa dapat mencapai peningkatan hasil belajar yang diharapkan dalam materi pembelajaran Teknik Elektronika Dasar.

Talking Stick termasuk salah satu model pembelajaran cooperative. Menurut (Spencer Kagan. 2000:1), belajar cooperative adalah suatu istilah yang digunakan dalam prosedur pembelajaran interactive, di mana siswa belajar bersama-sama dalam kelompok-kelompok kecil untuk memecahkan berbagai masalah. Setiap siswa tidak hanya menyelesaikan tugas individunya, tetapi juga berkewajiban membantu tugas teman kelompoknya, sampai semua anggota kelompok memahami suatu konsep.

Sedangkan menurut Johnson, model pembelajaran cooperative adalah strategi belajar yang menggunakan kelompok-kelompok kecil. Setiap kelompok dengan siswa dari tingkat kemampuan berbeda, menggunakan aktivitas belajar yang bervariasi untuk meningkatkan pemahaman mereka terhadap suatu konsep.

\section{Metodologi}

Metode pembelajaran digunakan oleh guru untuk mewujudkan suasana belajar dan proses pembelajaran agar peserta didik mencapai kompetensi dasar atau seperangkat indikator yang telah ditetapkan. Pemilihan metode pembelajaran disesuaikan dengan situasi dan kondisi peserta didik serta karakteristik dari setiap indikator dan kompetensi yang hendak dicapai dalam setiap mata pelajaran.

\section{1 .Rangkaian logika}

Gerbang dasar logika atau gerbang logik adalah suatu entitas dalam elektronika dan matematika boolean yang mengubah satu atau beberapa masukan logik menjadi sebuah sinyal keluaran logik. Gerbang logika terutama diimplementasikan secara elektronis menggunakan dioda atau transistor, akan tetapi dapat pula dibangun menggunakan susunan komponen-komponen yang memanfaatkan sifat-sifat elektromagnetik (relay). Logika merupakan dasar dari semua penalaran

(reasoning). Untuk menyatukan beberapa logika, kita membutuhkan operator logika dan untuk membuktikan kebenaran dari logika, kita dapat menggunakan tabel kebenaran. Tabel kebenaran menampilkan hubungan antara nilai kebenaran dari proposisi atomic, dengan tabel kebenaran, suatu persamaan logika ataupun proposisi bisa dicari nilai kebenarannya, tabel kebenaran pasti mempunyai banyak aplikasi yang dapat diterapkan karena mempunyai fungsi tersebut, salah satu dari aplikasi tersebut yaitu dengan menggunakan tabel kebenaran kita dapat mendesain suatu rangkaian logika, dalam makalah ini akan

dijelaskan bagaimana peran dan kegunaan tabel kebenaran dalam proses pendesainan suatu rangkaian logika. Gerbang yang diterjemahkan dari istilah asing (gate), adalah elemen dasar dari semua rangkaian yang menggunakan sistem digital. Semua fungsi digital pada dasarnya tersusun atas gabungan beberapa gerbang logika dasar yang disusun berdasarkan fungsi yang diinginkan, gerbang- gerbang dasar ini bekerja atas dasar logika tegangan yang digunakan dalam teknik digital, logika tegangan adalah asas dasar bagi gerbang- gerbang logika. Dalam teknik digital apa yang dinamakan logika tegangan adalah dua kondisi tegangan yang saling berlawanan, kondisi ada tegangan mempunyai istilah lain berlogika satu (1), atau berlogika tinggi (high), sedangkan tidak ada tegangan memiliki istilah lain berlogika nol (0), atau berlogika rendah (low).

Dalam membuat rangkaian logika kita menggunakan gerbang-gerbang logika yang sesuai dengan yang dibutuhkan, rangkaian digital adalah sistem yang mempresentasikan sinyal sebagai nilai diskrit, dalam sebuah sirkuit digital, sinyal direpresentasikan dengan satu dari dua macam kondisi yaitu 1 (high, active, true), dan 0 (low, nonactive, false).

Ada tujuh gerbang logika yang sering digunakan yaitu and, or, not/inverter, nand, nor, exclusive-or (exor), dan exclusive-nor (ex-nor), buffer (Hodges D, Jacson, Nasution S).

Variable biner dapat dijelaskan oleh tiga operasi logika dasar yaitu:

1. Operasi not (negation) 
2. Operasi and (conjuction)

3. Operasi or (disconjuction)

Operasi-operasi tersebut dapat dijelaskan dalam tiga bentuk yaitu:

1. Tabel fungsi (tabel kebenaran), yang menunjukan keadaan semua variabel masukan dan keluaran untuk setiap kemungkinan.

2. Simbol rangkaian untuk menjelaskan rangkaian digital.

\subsection{Perencanaan Pembelajaran}

Perencanaan pembelajaran merupakan aktivitas penetapan tujuan pembelajaran, penyusunan bahan ajar dan sumber belajar, pemilihan media pembelajaran, pemilihan pendekatan dan strategi.

pembelajaran, pengaturan lingkuan belajar, perancangan sistem penilaian hasil belajar serta perancangan prosedur pembelajaran dalam rangka membimbing peserta didik agar terjadi proses belajar, yang kesemuanya itu didasarkan pada pemikiranmendalam mengenai prinsip - prinsip pembelajaran yang tepat.

Perencanaan pembelajaran meliputi silabus dan rencana pelaksanaan pembelajaran yang memuat identitas mata pelajaran, standar kompetensi, kompetensi dasar, indikator pencapaian kompetensi, tujuan pembelajaran, materi ajar alokasi waktu, metode pembelajaran, kegiatan pembelajaran, penilaian hasil belajar, dan sumber belajar.

Perencanaan pembelajaran adalah merencanakan sistem untuk memulai suatu pelajaran selama waktu yang ditentukan. Pembuatan silabus, RPP, menentukan bahan ajar apa saja yang dipakai dan media apa yang digunakan oleh pendidik.

\subsection{Silabus}

Silabus diartikan sebagai rencana pembelajaran pada suaru dan/atau kelompok mata pelajaran atau tema tertentu yang mencangkup standar kompetensi, kompetensi dasar, materi pokok/pembelajaran, kegiatan pembelajaran, indikator pencapaian kompetensi untuk penilaian, alokasi waktu dan sumber belajar.

istilah silabus dapat didefinisikan sebagai garis besar ringkasan, ikhtisar, atau pokok - pokok isi atau materi pelajaran. Silabus digunakan untuk menyebut suatu produk pengembangan kurikulum berupa penjabaran lebih lanjut dari standar kompetensi dan kemampuan dasar yang ingin dicapai, dan pokok - pokok serta uraian materi yang perlu dipelajari siswa dalam mencapai standar kompetensi dan kemampuan dasar.

Silabus merupakan seperangkat rencana serta pengaturan pelaksanaan pembelajaran dan penilaian yang disusun secara sistematis memuat komponen - komponen yang saling berkaitan untuk mencapai penguasaan kompetensi dasar.

\subsection{Pengertian RPP}

Rencana Pelaksanaan Pembelajaran (RPP) adalah rencana kegiatan pembelajaran tatap muka untuk satu pertemuan atau lebih. RPP dikembangkan secara rinci dari suatu materi pokok atau tema tertentu yang mengacu pada silabus untuk mengarahkan kegiatan pembelajaran siswa dalam upaya mencapai Kompetensi Dasar (KD). Setiap pendidik pada tiap satuan pendidikan berkewajiban menyusun RPP secara lengkap dan sistematis agar pembelajaran berlangsung secara interaktif, inspiratif, menyenangkan, menantang, efisien, dan memotivasi siswa untuk berpartisipasi aktif serta memberikan ruang yang cukup bagi prakarsa, kretivitas, dan kemandirian sesuai dengan bakat, minat, perkembangan fisik serta psikologis siswa.

RPP disusun berdasarkan KD atau subtema yang dilaksanakan dalam satu kali pertemuan atau lebih.

\subsection{Tujuan dan Manfaat RPP}

Rencana Pelaksanaan Pembelajaran (RPP) merupakan bagian penting dalam proses belajar mengajar di sekolah. Melalui perencanaan yang baik, guru akan lebih mudah dalam melaksanakan pembelajaran dan murid akan lebih terbantu dan lebih mudah menangkap pelajaran serta berfungsi untuk mengefektifkan proses pembelajaran agar sesuai dengan yang telah direncanakan. Perencanaan pembelajaran dikembangkan sesuai dengan kebutuhan dan karakteristik peserta didik, sekolah, dan mata pelajaran.

\subsection{Komponen Penyusunan RPP}

Komponen RPP kurikulum 2013 yaitu sebagai berikut:

a. Identitas Sekolah Identitas Mata Pelajaran

Identitas mata pelajaran dalam RPP kurikulum 2013 terdiri dari :

1) Satuan Pendidikan

2) Kelas

3) Semester

4) Program Studi

5) Mata Pelajaran atau Tema Pelajaran

6) Jumlah Pertemuan

\section{b. Kompetensi Inti}


Kompetensi inti merupakan kualifikasi kemampuan minimal peserta didik yang menggambarkan penguasaan pengetahuan, sikap, dan keterampilan yang diharapkan dicapai pada setiap kelas dan atau semester pada suatu mata pelajaran.

\section{c. Kompetensi Dasar}

Merupakan sejumlah kemampuan yang harus dikuasai peserta didik dalam mata pelajaran tertentu sebagai rujukan penyusunan indikator kompetensi dalam suatu pelajaran.

\section{d. Indikator Pencapaian Kompetensi}

Adalah perilaku yang dapat diukur atau diobservasi untuk menunjukkan ketercapaian kompetensi dasar tertentu yang menjadi acuan penilaian mata pelajaran. Indikator pencapaian kompetensi dirumuskan dengan menggunakan kata kerja operasional yang dapat diamati dan diukur yang mencakup pengetahuan, sikap, dan keterampilan.

\section{e. Tujuan Pembelajaran}

Tujuan pembelajaran menggambarkan proses dan hasil belajar yang diharapkan dicapai oleh peserta didik sesuai dengan kompetensi dasar.

\section{f. Materi Pembelajaran}

Materi pembelajaran memuat fakta, konsep, prinsip, dan prosedur yang relevan dan ditulis dalam bentuk butir-butir sesuai dengan rumusan indikator ketercapaian kompetensi.

\section{g. Alokasi Waktu}

Alokasi waktu ditentukan sesuai dengan keperluan untuk pencapaian kompetensi dasar dan beban belajar dengan mempertimbangkan jumlah jam pelajaran yang tersedia dalam silabus dan kompetensi dasar yang harus dicapai.

\subsection{Kegiatan Pembelajaran}

Untuk mencapai kompetensi dasar harus dicantumkan langkah-langkah kegiatan setiap pertemuan. Pada dasarnya langkah-langkah kegiatan memuat unsur kegiatan sebagai berikut:

1) Pendahuluan/pembuka

Pendahuluan merupakan kegiatan awal dalam suatu pertemuan pembelajaran yang ditunjukan untuk membangkitkan motivasi dan memfokuskan perhatian peserta didik untuk berpartisipasi aktif dalam proses pembelajaran.

2) Kegiatan inti terdiri atas eksplorasi, elaborasi, dan konfirmasi Kegiatan inti merupakan proses pembelajaran untuk mencapai KD. Kegiatan pembelajaran dilakukan secara iteraktif, inspiratif, menyenangkan, menantang, memotivasi peserta didik untuk berpartisipasi aktif, serta memberi ruang yang cukup bagi prakarsa, kreativitas, dan kemandirian sesuai dengan bakat, minat, dan perkembangan fisik serta psikologis peserta didik. Kegiatan inti dilakuan secara sistematis dan sistematik melalui proses eksplorasi, elaborasi, dan konfirmasi.

3) Kegiatan penutup.

Penutup merukapan kegiatan yang dilakukan untuk mengakhiri aktivitas pembelajaran yang dapat dilakukan dalam bentuk rangkuman atau simpulan, penilaian dan refleksi, umpan balik, dan tinda lanjut.

\subsection{Sumber Pembelajaran}

Penentuan sumber belajar didasarkan pada standar kompetensi dan kompetensi dasar serta materi ajar, kegiatan pembelajaran, dan indikator pencapaian kompetensi yang dapat berupa buku, media cetak dan elektronik, alam sekitar, atau sumber belajar lain yang relevan.

\section{Hasil dan Pembahasan}

Prosedur, instrumen penilaian proses, dan hasil belajar disesuaikan dengan indikator pencapaian kompetensi dan mengacu kepada Standar Penilaian.

\subsection{Model Pembelajaran Talking Stick}

Talking Stick (tongkat berbicara), model yang pada mulanya digunakan oleh penduduk asli Amerika untuk mengajak semua orang berbicara atau menyampaikan pendapat dalam suatu forum (pertemuan antarsuku). Talking Stick (tongkat berbicara), telah digunakan selama berabad-abad oleh suku Indian sebagai alat menyimak secara adil dan tidak memihak, tongkat berbicara sering digunakan kalangan dewan untuk memutuskan siapa yang mempunyai hak berbicara, pada saat pemimpin rapat mulai berdiskusi dan membahas permasalahan ia harus memegang tongkat, tongkat akan berpindah ke orang lain apabila ia ingin berbicara atau menanggapinya, apabila semua mendapat giliran berbicara, tongkat itu lalu dikembalikan lagi ke ketua atau pemimpin rapat, dari 
penjelasan di atas dapat disimpulkan bahwa Talking Stick dipakai sebagai tanda seseorang mempunyai hak suara (berbicara), yang diberikan secara bergiliran atau bergantian.

Model pembelajaran Talking Stick termasuk salah satu model pembelajaran cooperative. Strategi pembelajaran ini dilakukan dengan bantuan tongkat, siapa yang memegang tongkat wajib menjawab pertanyaan dari guru setelah peserta didik mempelajari materi pokok. Model pembelajaran Talking Stick sangat cocok diterapkan bagi peserta didik SD, SMP, dan SMA/SMK. Selain untuk melatih berbicara, pembelajaran ini akan menciptakan suasana yang menyenangkan dan membuat peserta didik aktif.

Pembelajaran dengan strategi Talking Stick mendorong peserta didik untuk berani mengemukakan pendapat, strategi ini di awali dengan penjelasan guru mengenai materi pokok yang akan dipelajari, kemudian dengan bantuan Stick (tongkat) yang bergulir peserta didik dituntun merefleksikan atau mengulang materi yang sudah dipelajari dengan cara menjawab pertanyaan dari guru, siapa yang memegang tongkat, dialah yang wajib menjawab pertanyaan (Agus suprijono, 2010:109)

\section{Kesimpulan}

Pendidikan merupakan aspek kehidupan yang mendasar bagi pembangunan bangsa. Melalui pendidikan manusia dapat menemukan hal hal baru yang dapat dikembangkan dan diperoleh untuk menghadapi antangan yang ada sesuai dengan perkembangan zaman. Sekolah sebagai penyelenggara pendidikan bertujuan untuk mengembangkan potensi siswa. Pendidikan di sekolah merupakan proses yang melibatkan beberapa unsur yang saling berhubungan yaitu guru, siswa, kurikulum dan sarana prasarana. Unsur - unsur pendidikan diharapkan mampu menciptakan pendidikan yang berkualitas melalui proses pembelajaran.

Rencana Pelaksanaan Pembelajaran (RPP) merupakan bagian penting dalam proses belajar mengajar di sekolah. Melalui perencanaan yang baik, guru akan lebih mudah dalam melaksanakan pembelajaran dan murid akan lebih terbantu dan lebih mudah menangkap pelajaran serta berfungsi untuk mengefektifkan proses pembelajaran agar sesuai dengan yang telah direncanakan. Perencanaan pembelajaran dikembangkan sesuai dengan kebutuhan dan karakteristik peserta didik, sekolah, dan mata pelajaran.

Dari beberapa aspek diatas maka makalah komprehensif ini bertujuan untuk membuat guru-guru atau pengajar lebih memperhatikan seberapa pentingnya pembuatan rencana pelaksanaan pembelajaran (RPP) dalam proses pembelajaran,sehingga materi-materi yang akan di sampaikan dapat di terima oleh para peserta didik dengan baik dan agar dapat memotivasi peserta didik dalam proses belajar dan maanfaat bagipada peserta didik adalah agar peserta didik lebih termotivasi dan mampu mempelajari materi pembelajaran dengan baik sehingga meningkatkan hasil belajar.

\section{DAFTAR PUSTAKA}

1. Badan Standar Nasional. (2006). Panduan penyusunan kurikulum tingkat satuan pendidikan jenjang pendidikandasar dan menengah.

2. Depdiknas. (2004). Perpustakaan perguruan tinggi: buku pedoman, edisi ketiga. Jakarta: Depdiknas.

3. Depdiknas. (2008). Kurikulum tingkat satuan pendidikan. Jakarta: Dikmenum. Depdiknas.

4. Dick and Carey. (2005). Ddesain system intruksional.

5. Hermawan. (2007). Media pembelajaran SD. Bandung: Upi press.

6. Hodges D, Jacson, Nasution S. http://pembelajaranfisikauki.blogspot.co.id/2016/03/gerbang$\underline{\text { logika.html }}$

7. Kagan Spencer. (2008). Model pembelajaran kooperatif tipe Talking Stick.

8. KBBI. (1991). Kamus besar bahasa Indonesia. Jakarta. Departemen Pendidikan Nasional.

9. Kunandar. (2008). Langkah mudah penelitian tindakan kelas sebagai pengembangan profesi guru. Jakarta: PT. Rajagrafindopersada.

10. Nana Sudjana. (1987). Dasar-dasar proses belajar mengajar. Bandung: sinar baru algensindo.

11. Permendiknas. (2007). Tentang standard proses untuk satuan pendidikan dasar dan menengah.

12. Permendikbud. (2014). Tentang pedoman pelaksanaan pembelajaran.

13. Senjaya Wina. (2010). Strategi pembelajaran berorientasi standard proses pendidikan. Jakarta: Prenada media group.

14. Suparman Atwi. (2012). Desain inttruksional modern. Jakart: Erlangga.

15. Suprijono Agus. (2010). Cooperative learning. Yogyakarta. Pustaka media.

16. Suyanto. (2009). Menjelajah pembelajaran inovatif. Sidoarjo: Masmedia buana pusaka.

17. Trianto. (1991). Model-model pembelajaran inovatif berorientasi.

18. W, Gulo. (1987). Strategi belajar mengajar. 